\title{
Serum Concentrations of Procollagen Type III Aminoterminal Peptide in Growing Dogs with Hip Dysplasia
}

The aim of the present study was to investigate the use of procollagen type III aminoterminal peptide (PIIINP) measurements in serum as an indicator of progress of fibrosis of coxofemoral joint capsules in hip dysplasia in immature dogs. High serum concentrations of PIIINP may indicate ongoing fibrosis with enhanced synthesis and deposition of fibrillar type III collagen, or an alteration in degradation and elimination of circulating PIIINP (Hørslev-Petersen et al. 1988a). Therefore, high concentrations of PIIINP in serum was expected in dogs with hip dysplasia, which is a developmental condition with capsular fibrosis and osteoarthritis (Gay et al. 1986).

The design of the study included measurements of the concentrations of PIIINP in serum from dogs during their first 6 months of life. Earlier reports have shown high concentrations of PIIINP in serum and synovial fluids in growing (Trivedi et al. 1986) and in osteoarthritic animals (Hørslev-Petersen et al. 1988b, Madsen et al. 1990). These observations support our working hypothesis that increased fibrillogenesis of collagen type III is an early feature of hip dysplasia in dogs.

The present study comprised 23 German shepherd dogs from 6 litters. Serum was obtained from all dogs at the age of 2 weeks, 6 weeks, and 26 weeks. At the age of 6 and 12 months the dogs were examined clinically and radiographically with respect to their hip status. The clinical examination included the Ortolani test for coxofemoral joint laxity (Chalman \& Butter 1985), and was performed before and after administration of Xylazine $(1.3 \mathrm{mg} / \mathrm{kg}$; IM). Dogs were excluded from the study if the clinical examination or the history indicated any disease except hip dysplasia. At the radiographic examination a standardized method for obtaining pelvic radiographs was used (Rendano \& Ryan 1985). Hip dysplasia was B2 or worse according to the criteria approved by Fédération Cynologique Internationale (Brass et al. 1978). Diagnoses were made when the dogs were 12 months old, and dogs with the radiographic evidence of other pelvic diseases were excluded from the study.

The concentrations of intact and high molecular weight PIIINP antigens were determined by an equilibrium type radioimmunoassay ${ }^{\mathrm{a}}$ (Risteli et al. 1988). The methodology, which is well documented in human beings (Risteli \& Risteli 1990), is based on the fact that PIIINP is liberated into the extracellular fluid during fibrillogenesis of collagen type III. Increased concentrations of PIIINP have been detected in humans with active arthritis (Hørslev-Petersen et al. 1988b), in growth (Trivedi et al. 1986), and in diseases in which collagen syn-

\footnotetext{
${ }^{\text {a }}$ PIIINP-RIA Kit, Farmos Diagnostica, Oulunsalo, Finland.
} 
Table 1. Results of the measurements of PIIINP in serum from 23 dogs sampled at the age of 2,6 , and 26 weeks.

\begin{tabular}{|c|c|c|c|c|c|}
\hline \multirow{2}{*}{ Dog } & \multicolumn{3}{|c|}{ Concentrations of PIIINP $(\mu \mathrm{g} / \mathrm{l})$} & \multirow{2}{*}{$\underset{\text { dysplasia }}{\text { Hip }}$} & \\
\hline & 2 weeks & 6 weeks & 26 weeks & & \\
\hline 1 & 578 & 588 & ND & NO & \\
\hline 2 & 1003 & 582 & 694 & NO & * \\
\hline 3 & 388 & 720 & 205 & NO & * \\
\hline 4 & 236 & 510 & 403 & NO & \\
\hline 5 & 814 & 383 & 176 & NO & \\
\hline 6 & 1168 & 508 & 232 & NO & \\
\hline 7 & 783 & 473 & 320 & NO & \\
\hline 8 & 858 & 695 & 358 & NO & \\
\hline 9 & 655 & 423 & 203 & NO & * \\
\hline 10 & 850 & 428 & 365 & NO & * \\
\hline 11 & 832 & 478 & 248 & NO & * \\
\hline 12 & 424 & 915 & 415 & YES & * \\
\hline 13 & 1280 & 635 & 363 & YES & \\
\hline 14 & 2080 & 990 & 245 & YES & * \\
\hline 15 & 1136 & 640 & 446 & YES & * \\
\hline 16 & 996 & 468 & 313 & YES & $*$ \\
\hline 17 & 962 & 403 & 330 & YES & * \\
\hline 18 & 768 & 518 & 385 & YES & * \\
\hline 19 & 843 & 682 & 264 & YES & \\
\hline 20 & 925 & 620 & ND & YES & * \\
\hline 21 & 330 & 403 & 188 & YES & * \\
\hline 22 & 1108 & 378 & 255 & YES & * \\
\hline 23 & 940 & 510 & 322 & YES & $*$ \\
\hline \multicolumn{6}{|c|}{ Median/Range Q1-Q3 } \\
\hline Dysplastic & $951 / 806-1122$ & $569 / 436-661$ & $322 / 255-385$ & & \\
\hline Not dysplastic & $814 / 578-858$ & $508 / 428-588$ & $284 / 205-365$ & & \\
\hline Joint laxity & 933/717-1056 & $514 / 426-638$ & $322 / 245-385$ & & \\
\hline Tight joints & $814 / 578-858$ & $510 / 473-682$ & $292 / 232-358$ & & \\
\hline $\mathrm{p}_{\text {normal }<>\text { dysplastic }}$ & 0.12 & 0.54 & 0.51 & & \\
\hline $\mathrm{p}_{\text {lax }<>\text { tight joints }}$ & 0.30 & 0.95 & 0.56 & & \\
\hline
\end{tabular}

* Dogs showing coxofemoral joint laxity at the age of 6 or 12 months.

$\mathrm{ND}=$ Not determined.

Medians and ranges from 25 to 75 percentiles are shown (Q1-Q3) by age group and severity of hip dysplasia.

$P$ show the probability of the Mann Whitney test that there are no differences between affected and normal dogs.

thesis is increased (Fesslev \& Fesslev 1978) or where the metabolism of the peptide is changed (Hørslev-Petersen et al. 1988a, Bentsen et al. 1989).

Statistical analyses were performed on computer using the procedures NPAR1WAY
ANOVA WILCOXON of the Statistical Analysing System SAS Institute Inc. 1988). Nonparametric statistical analysis, the Mann Whitney rank sum test for unpaired observations, was used to establish if there was a statistical difference between the concentrations 
of PIIINP in serum from dogs with and without coxofemoral joint laxity or hip dysplasia.

In the present study, the concentrations of serum PIIINP were higher in dogs with hip dysplasia or coxofemoral joint laxity than in normal dogs, but differences were not significant (Table 1). The PIIINP concentration in serum decreased to one third from the age of 2 weeks to the age of 26 weeks (Table 1). It is known that the PIIINP concentration is related to growth velocity (Trivedi et al. 1986). Therefore, it is of great importance to know the exact age of the dog from which the PIIINP concentrations in serum are evaluated.

Recent studies in older dogs show that measurements of the concentrations of PIIINP in synovial fluid reflect the progress of capsular fibrosis better than measurements in serum (Madsen et al. 1990). Concentrations of the peptide in serum might be low if the progression of fibrosis is very slow or interrupted or if the metabolism of the peptide is increased. Contrary, the PIIINP concentrations should increase with exacerbations of joint disease. These phenomena may explain the great variation in the concentrations of PIIINP seen in this study, and consequently the absence of significant differences between dogs with and without hip dysplasia.

In conclusion, the present study did not support the hypothesis that increased fibrillogenesis of collagen type III is an early feature of hip dysplasia. Still, the latter hypothesis may be correct, and statistically significantly elevated mean concentrations of PIIINP in serum may occur in larger populations. Based on the observation of overlapping ranges between normal and dysplastic dogs, we decided to terminate the study. Still, measurements of PIIINP concentrations of serum may give information about progression of joint diseases of the individual dog, but the measurements are not diagnostic for hip dysplasia in immature dogs.

\section{Acknowledgements}

This study was supported by a Grant from Upjohn.

\section{J.S. Madsen, E. Svalastoga}

Department of Clinical Studies, Small Animal Hospital, The Royal Veterinary and Agricultural University, Bülowsvej 13, DK-1870 Frederiksberg C, Denmark.

\section{L.T. Jensen}

Department of Medicine, Division of Rheumatology, University of Copenhagen, Hvidovre Hospital, DK-2650 Hvidovre, Denmark.

\section{References}

Bentsen KD, Henriksen JH, Boesby S, Hørslev-Petersen $K$, Lorenzen I: Hepatitic and renal extraction of circulating type III procollagen aminoterminal propeptide and hyaluronan in pigs. J. Hepatol. (Amst.) 1989, 9, 177-183.

Brass von W, Freudiger U, Müller LF, Paatsama $S$, Velden van der NA, Watering van der CC: Bericht der Hüftgelenkdysplasie-Kommission. Kleintierpraxis, 1978, 23, 169-180.

Chalman JA, Butler HC: Coxofemoral joint laxity and the ortolani sign. J. Amer. Anim. Hosp. Assoc. 1985. 21, 671-676.

Fessler JH, Fessler LJ: Biosynthesis of procollagen. Ann. Rev. Biochem. 1978, 47, 129-162.

Gay S, Muller PK, Lemmer C, Remberger K, Matzen $K$, Kühn $K$ : Immunohistological study on collagen in cartilage-bone metamorphosis and degenerative osteoarthritis. Klin. Wochenschr. 1976. 54, 969-976.

Hørslev-Petersen K. Kim KY, Pedersen LR, Bentsen $K D$, Uldbjerg N, Oxlund H, Garbaarsch C, Hahn $E G$, Schuppan D, Lorenzen I: Serum aminoterminal type III procollagen peptide. Relation to biosynthesis of collagen type III in experimental induced granulation tissue in rats. Acta Pathol. Microbiol. Immunol. Scand. 1988a. 96, 793-804. 
Hørslev-Petersen K, Saxne T, Haar P, Thomsen BS, Bentsen KD, Junker $P$, Lorenzen I: The aminoterminal type III procollagen peptide and proteoglycans in serum and synovial fluid of patients with rheumatoid arthritis or reactive arthritis. Rheumatol. Int. 1988b, 8, 1-9.

Madsen JS, Jensen LT, Strøm H, Hørslev-Petersen K, Svalastoga E: Procollagen type III aminoterminal peptide in serum and synovial fluid of dogs with hip dysplasia and coxarthrosis. Amer. J. vet. Res. 1990, 51, 1544-1546.

Rendano VT, Ryan G: Canine hip dysplasi evaluation. Vet. Radiol. 1985, 26, 170-186.

Risteli J, Nemi S, Trivedi P, Mäentausta $O$, Mowat $A P$, Risteli L: Rapid equilibrium radioimmunoassay for the aminoterminal propeptide of hu- man type III procollagen. Clin. Chem. 1988, 34, 715-718.

Risteli L, Risteli J: Non-invasive methods for detection of organ fibrosis. In: Rojkind M: Focus on connective tissue in health and disease. Vol. 1, ed. 1, Florida, CRC Press Inc., Boca Raton, 1990, pp. 61-98.

SAS Institute Inc: SAS/STAT Users Guide, Version 6.03, Cary, NC, USA, 1988.

Trivedi $P$, Cheeseman P, Mowat AP: Serum type III procollagen peptide as a non-invasive marker of liver damage during infancy and childhood in extrahepatic biliary atresia, idiopathic hepatitis of infancy and alpha 1 antitrypsin deficiency. Clin. Chem. Acta, 1986, 161, 137-146.

(Received July 15, 1993; accepted February 6, 1995).

Reprints may be requested from: J. Madsen, Department of Clinical Studies, Small Animal Hospital, The Royal Veterinary and Agricultural University, Bülowsvej 13, DK-1870 Frederiksberg C, Denmark. 